
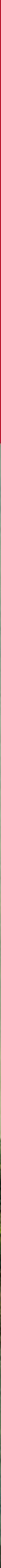


\section{Samuel Clark}

\section{The politics of heraldry}

Steven Thiry, Matter(s) of state. Heraldic display and discourse in the early modern Monarchy (c. 1480-1650) (Ostfildern: Jan Thorbecke Verlag, 2018, 401 p., ill., index)

In this work of exceptional scholarship, Steven Thiry examines the politics of royal heraldry from the late-fifteenth century to the mid-seventeenth century in the Spanish Habsburg and French monarchies. He wants to rectify the neglect of heraldry by most historians, which he believes is a failing even in the new cultural-history literature. He laments in particular the neglect of heraldry in recent work on royal visual representation. He is also critical of the tendency of most research in cultural history to focus on a single country. Only in a comparative framework can one understand and explain the place of royal heraldry in both domestic and international power struggles.

The aim of the book is to demonstrate the interconnection among a number of causal processes. The major process that he examines is the effect of state structures, political conjunctures, and geography on royal arms. Royal heraldry and modifications to royal arms were framed in ways that could serve to legitimate regimes or assert the superiority of a dynasty or political system. Royal arms were created and recreated by the French crown in an effort to promote the unity of the French kingdom and by the Habsburgs to recognize simultaneously the unity and diversity of their domains. Both the French and Spanish rulers sought to increase their power, which in both cases meant political centralization. Yet this process varied greatly across Europe and was far more difficult for the Austrian and Spanish Habsburgs than for French kings. Generally speaking, as European monarchies became more sedentary, royal arms became more useful as a way of extending their power. Not surprisingly they 


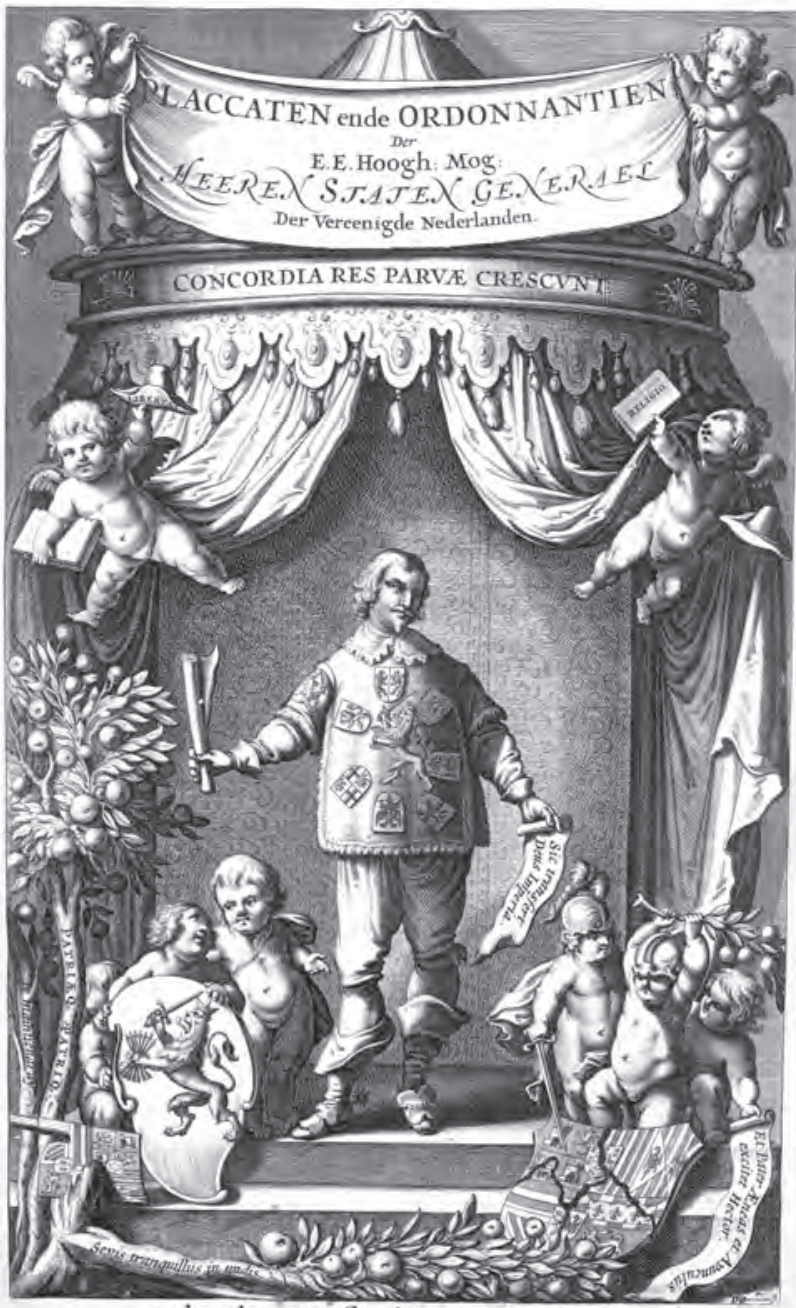

Gedruckt t'Amfrerdam bij lan Ianßen.
'Herald of the Dutch

Republic'. Frontispice by

Daniël van den Bremden of the Nederlandtsche

placcaet-boeck (Amsterdam, Johannes Janssonius, 1644) (collection Rijksmuseum, Amsterdam)

were seen as more important for managing the far-flung Habsburg territories than the more geographically cohesive territories of the French crown. The mechanism for this extension of royal power was the popular (though by no means unanimous) belief that royal arms embodied the physical presence of the sovereign just as the body of Christ was present in the consecrated Host.

Rulers could also make coats of arms serve as honorific rewards. A new coat of arms or an alteration to an existing coat of arms could be given royal recognition. In special cases a family might be allowed to incorporate parts of the royal arms into their own coat of arms. This might be done to reward or encourage services to the crown, to secure and proclaim loyalty and personal ties, or to strengthen alliances. Coats of arms were different from other modes 
of communication, including other honorific rewards. Like the medals and badges that became the major form of state honorific reward in later centuries, coats of arms were relatively inexpensive and could be transported or reproduced in large numbers throughout a realm. Much more than medals or badges, however, they could potentially meet relatively complex objectives and be adapted to different circumstances and contingencies. And medals or badges did not have the mystical connection to the person of the king that royal coats of arms possessed.

As we might expect political conjunctures had consequences for royal heraldry. Royal successions and territorial acquisitions inevitably led to heraldic adaptations. Thiry observes that periods of conflict, political struggles, royal vulnerability, and rebellion correlated with periods of radical heraldic changes. Such was the case, he notes, during the English Civil War, the French Revolution, the French Wars of Religion, and the Revolt of the Netherlands. He has a chapter on the latter two.

Thiry is insistent that he is not making what he calls a 'propagandist' argument, by which he means a view that a centrally directed authority imposed itself on a passive audience by conveying a positive image of the head of state. Royal insignia were not tabula rasa that royal officials could use to convey a holistic celebratory message. Nor were they static advertisements or promotions of a predetermined position. Multiple actors participated in their construction. Clerics, legists, historians, ceremonialists, noblemen, humanists, and designers of emblems were among those who had something to say about royal heraldry. And members of the larger public could engage in what he calls 'symbolic negotiation'. Even the illiterate were far from ignorant about coats of arms and could react to the visual images in their own ways. In fact, according to Thiry, coats of arms themselves acquired agency in so far as they provoked new acts of signification and came to have meanings different from the intentions of those who created or modified them.

The reality was that heraldry was a double-edged sword, especially in the Habsburg monarchy as a result of its territorial diversity and greater acceptance of heraldic variety. Consequently, the Spanish Habsburg monarchy had to be more careful in using heraldry to reward powerful families and granting them the right to insert parts of the royal arms into their own arms. These practices could lead to an alienation of royal power. Even in France strict exclusivity of royal arms could not be enforced.

If the crown employed armorial legends in an effort to sanctify the origin of the royal arms, others could employ legends for their own purposes. If the crown could seek to use heraldry for legitimation purposes, others could try to use heraldry to legitimate their dynastic claims. Territories that were incorporated into a monarchy could use their traditional arms to assert a measure of independence. Most notably, the provinces of the Low Countries used heraldry to assert their independence during their revolt against Spanish rule and subsequently during the formation of the Dutch federation. And anyone, regardless of their armigerous status, could try to use heraldry for symbolic purposes. As Thiry demonstrates from the very first page, the disaffected could damage royal arms, seeing this as a way of rejecting the legitimacy of a monarchy. Indeed, if one bought the idea that the royal coat of arms was a physical incarnation of the body of the ruler, a physical attack on it could be seen as a physical attack on that very body. During the French Wars of Religion and to a lesser ex- 
tent the Revolt of the Netherlands, physical attacks on royal arms - 'heraldic iconoclasm' or 'heraldoclasm' to adopt the author's terms - were numerous.

Thus far I have reviewed what Thiry says about the effect of political structures, historical conjunctures, power struggles, and so forth on heraldry, as monarchies and other actors endeavored to use it for their various purposes. He is, however, also interested in the reverse causal process, that is, the causal force that heraldry had owing to its symbolic power. Obviously, the ways in which monarchies and other actors tried to use heraldry indicates that they believed that heraldry had effective symbolic power. Unfortunately, it is difficult to determine its effects empirically. What would persuade us that royal arms or their modifications had significant consequences, whether or not these consequences were what the creators wanted? Did these consequences make much difference in comparison with the great number of other causal processes operating in these societies?

I would suggest that the consequences varied. Least questionable are the cultural effects of royal arms. The respect in which they were held in the population provides some evidence that royal arms contributed to the legitimation of monarchies. Thiry also provides sufficient reason to believe that earlier coats of arms or heraldic traditions impacted later heraldic symbols; in particular he demonstrates that in the Habsburg territories the history of heraldic diversity in various regions and modifications to heraldic symbols substantially influenced later heraldic creations and modifications. It is also clear that rejection of any heraldic symbol would have led to its replacement. Heraldic iconoclasm must have encouraged further heraldic iconoclasm through processes that are well known in the literature on collective action. We can also accept Thiry's argument that coats of arms to some extent created new meaning. And it is reasonable for us to accept his claim that heraldic literature and the fashioning and refashioning of royal arms had effects on other modes of symbolic display.

Did the use of coats of arms as honorific rewards have much effect? It does seem that these concessions operated like contracts in a world in which personal bonds were critical throughout the society; sharing parts of royal arms would communicate personal ties, alliances, and loyalties. On the other hand, Thiry points out that beneficiaries could fail to implement the concession. And no doubt many recipients believed the concession they received was something owed to them rather than a benevolent reward.

On the whole, Thiry does not provide much evidence of the consequences of these rewards. This is not meant as a criticism. Documenting the consequences of honorific rewards is extremely difficult. Efforts are being made currently by researchers in a number of disciplines, especially economics and psychology, to find evidence about the effects of honorific rewards on people's behavior. The findings so far suggest that such rewards are effective for some purposes and in some contexts. Methodologically, this research is challenging, and impossible to do properly with the data that are available for early modern Europe.

Finally, what of the impact of heraldry on state formation? Thiry time and again alleges that its effects were significant, though to repeat, not necessarily the effects intended by the participants. As said, one effect that we can probably accept is that royal coats of arms helped to legitimate regimes. If so, attacks on royal arms must to some extent have undermined this legitimacy. In addition, such attacks would cause a negative reaction among some people, and thus, as the author suggests, threaten to undermine a sense of community. By the same 
token, I think we can agree that in so far as the integrity of royal heraldry was successfully maintained, it would to a degree have had a unifying effect.

For the most part, however, evidence of the impact of heraldry on state structures and political processes is lacking in this book; and there is certainly insufficient evidence to evaluate its effects relative to other causal forces operating in these structures and processes. Even the positive or negative impact of royal arms on the legitimation of regimes can be only a secondary factor in what determined royal legitimacy. Other forces played a much greater role. The monarchy of Louis XVI did not lose its legitimacy because of his heraldic arms or assaults on them.

In view of this lack of evidence, the bold claims Thiry makes about the effect of heraldry on state structures and processes is disturbing. I could provide numerous examples, but here are a few: "heraldic display and discourse was the stabilizing "matter" upon which unsteady political associations could be erected'; royal coats of arms and the way in which they were negotiated 'helped to define, produce, or modify the foundations of the political order'; and heraldic signs 'structured political authority in an all-pervasive hierarchy'. He needs a lot more evidence than he has to persuade readers that heraldry had such monumental consequences.

Nevertheless, this is a fine book, clearly the product of years of research. It reveals the changing pressures faced by two (very different) early modern monarchies. It informs us about public opinion at a time when we have rather limited sources of information about what most people thought. It demonstrates how seriously people took heraldry during the period he examines. Above all, of course, it focuses attention on a phenomenon that has generally been neglected by historians; and it provides us with a wealth of information on the subject. Heraldry today is a historical product of heraldry in the past and the forces that shaped it. This book makes a major contribution to getting that history right. It is essential reading for anyone interested in early modern European history. 
Houses divided? Noble familial and class connections during the Age of Revolution and Napoleon

\section{Mary K. Robinson}

'Le marriage m'a toujours fait peur.' Ongehuwde adellijke vrouwen in de zeventiende en achttiende eeuw

\section{Evelyn Ligtenberg}

Steekpenning of welkomstgeschenk? De strijd voor eerherstel van Gerrit Burchard en Adolf Hendrik van Rechteren

\section{Michel Hoenderboom}

The politics of presence. Place making among the Swedish iron producers in the county of Västmanland ca. 1750-1850

Marie Steinrud

De Belgische orangistische adel, deel II. De rol van de adel in het Belgisch orangisme (1830-1850)

Els Witte 